Original article

Central Eur J Paed 2017;13(1):55-61.

DOI $10.5457 /$ p2005-114.170

\title{
THE EPIDEMIOLOGICAL CHARACTERISTICS OF MEASLES MORBIDITY IN THE CENTRAL BOSNIA CANTON, 1997-2017
}

\author{
Sead KARAKAŠ, Lazar ĐURĐEVIĆ, Mika SKENDERIJA, Miroslav ŠAKIĆ
}

The Institute of Public Health of the Central Bosnia Canton, Travnik Bosnia and Herzegovina

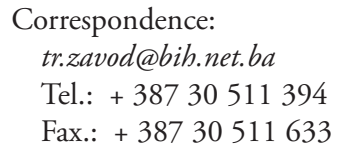

Correspondence: tr.zavod@bih.net.ba Tel.: + 38730511394

Fax.: + 38730511633

Received: January 15, 2017

Accepted: February 28, 2017

Key words: Epidemic - Measles Vaccine - Children.
Objective - The aim of the research was to show the occurrence and persistence of measles morbidity over a twenty year period in the area of the Central Bosnia Canton (Bosnia and Herzegovina). Materials and methods - The research was retrospective and related to the period from 1997 to 2017. The sample comprised a total of 35,199 children. The subjects were considered in relation to their age, gender, place of residence, vaccination status and time of morbidity. Results - In the period from 1997 to 2017, on average 36 cases of morbidity caused by measles occurred each year. Most years in this period (13) did not have any registered cases of measles, and in five years the disease occurred sporadically: 1999 (three cases); 2000 (one); 2003 (one); 2005 (two); 2009 (one), and two epidemics occurred: in 1997, with 77 affected children and with an incidence rate in the population under consideration of 218/100,000; and in 2014 with an explosion of measles morbidity, when 639 affected children were registered $(1815 / 100,000)$. The average coverage with the first dose of MMR vaccine over the last twenty years was $87 \%$, and the poorest results were achieved in 2004, with 64\%. Conclusion - The epidemiological occurrence of measles in the area of four municipalities in central Bosnia is the result of omissions in the routine immunization programme.

\section{Introduction}

Measles is a highly contagious virus disease. An infected person becomes infectious one day after the prodromal period, right up until the rash fades. In this period, patients are extremely infectious, because it is possible in only one hour to transmit more than 5000 infectious measles virus particles through secretions, with the highest contagion index of $95 \%$. The measles virus survives in an external environment for up to two hours (1). With the introduction of the vaccine, the number of cases of measles began to fall, and that trend continued with the increase in coverage by vaccination (2). However, measles epidemics continue to occur in Europe, so it is necessary to increase efforts to eliminate measles from the region (3). Measles are still an important cause of global mortality, as stated in the joint document: "GIVS: Global Immunization Vision and Strategy 20062015" adopted by the key stakeholders: The World Health Organization (WHO), the United Nations (UN) and UNICEF (4).

As well as a reduction in mortality, most WHO regions have set goals to eliminate measles and report on the progress achieved (5). Many countries have achieved the continuation of a reduction in the incidence of 
mortality, and have even eliminated the endemic disease (6). However, there have been many reports published recently on epidemics of measles in countries with a high level of coverage by vaccination, and the $\mathrm{CDC}$ and WHO confirm that the incidence of measles in the world rose in 2010, due to major epidemics in some regions $(6,7)$.

In countries with a low incidence of measles, the strategy of elimination usually includes an urgent response to a single registered case, including confirmation of the diagnosis, the search for contacts and post-exposure prophylaxis. Post-exposure prophylaxis may also be vaccination, which is effective at the beginning of the illness, if it begins within 72 hours from exposure, or it may include passive immunization with immunoglobulin, especially outside that 72-hour window (8).

The aim of this research was to show the occurrence and persistence of measles morbidity in the area of the Central Bosnia Canton (Bosnia and Herzegovina) in a twentyyear period.

\section{Materials and methods}

\section{The field of the research}

The Central Bosnia Canton is an administrative unit of Bosnia and Herzegovina. It is located in the central part of Bosnia and Herzegovina, with an area of $3189 \mathrm{~km}^{2}$ and a population in 2015 of 251,714 inhabitants, of which 58,021 are children aged between 0 and 18 years (9). In 2015 there was a total of 1965 live births, the birth rate is $7.8 \%$, whilst the natural growth rate of the population is negative - at $1.25 \%$ o (10).

\section{Subjects and Methods}

The research was retrospective, relating to the period from 1997 to 2017. The sample covered a total of 35,199 children, aged from 0 to 18 years, living in that period in the area of four municipalities in the Central Bosnia

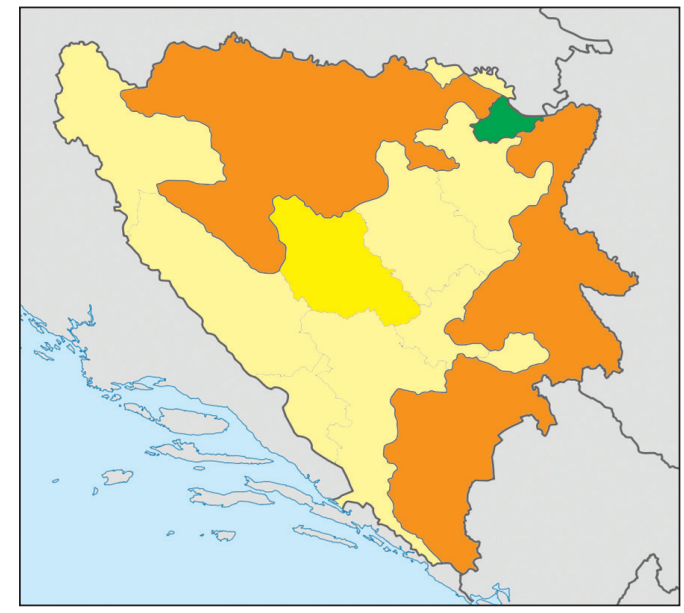

Fig. 1. The area of the Central Bosnia Canton of the Federation of Bosnia and Herzegovina coloured yellow, the area of the Federation of Bosnia and Herzegovina coloured light yellow, the area of Republika Srpska coloured orange, and the area of the Brcko district coloured green.

Canton (Travnik, 12,677; Novi Travnik, 6333; Vitez, 7406, and Bugojno, 8786). The sources of data for inclusion of children suffering from measles were: registration of infectious diseases in the existing documentation of the Institute of Public Health of the Central Bosnia Canton, the municipal epidemiological data on trends in infectious diseases, immunization plans and reports, and medical histories from the Canton Hospital in Travnik, where children suffering from measles were treated.

Data on the incidence of measles were analysed regarding sporadic and epidemic trends of the disease, and the number of affected children in relation to age, place of residence (village/town) and vaccination status. The diagnosis of measles was made on the basis of medical history and clinical findings, according to the WHO recommendations (11). Adequate immunization against measles was defined as documented evidence of vaccination at the age of 13 months, and re-vaccination at 6 years. The results obtained are shown in absolute and relative numbers. 


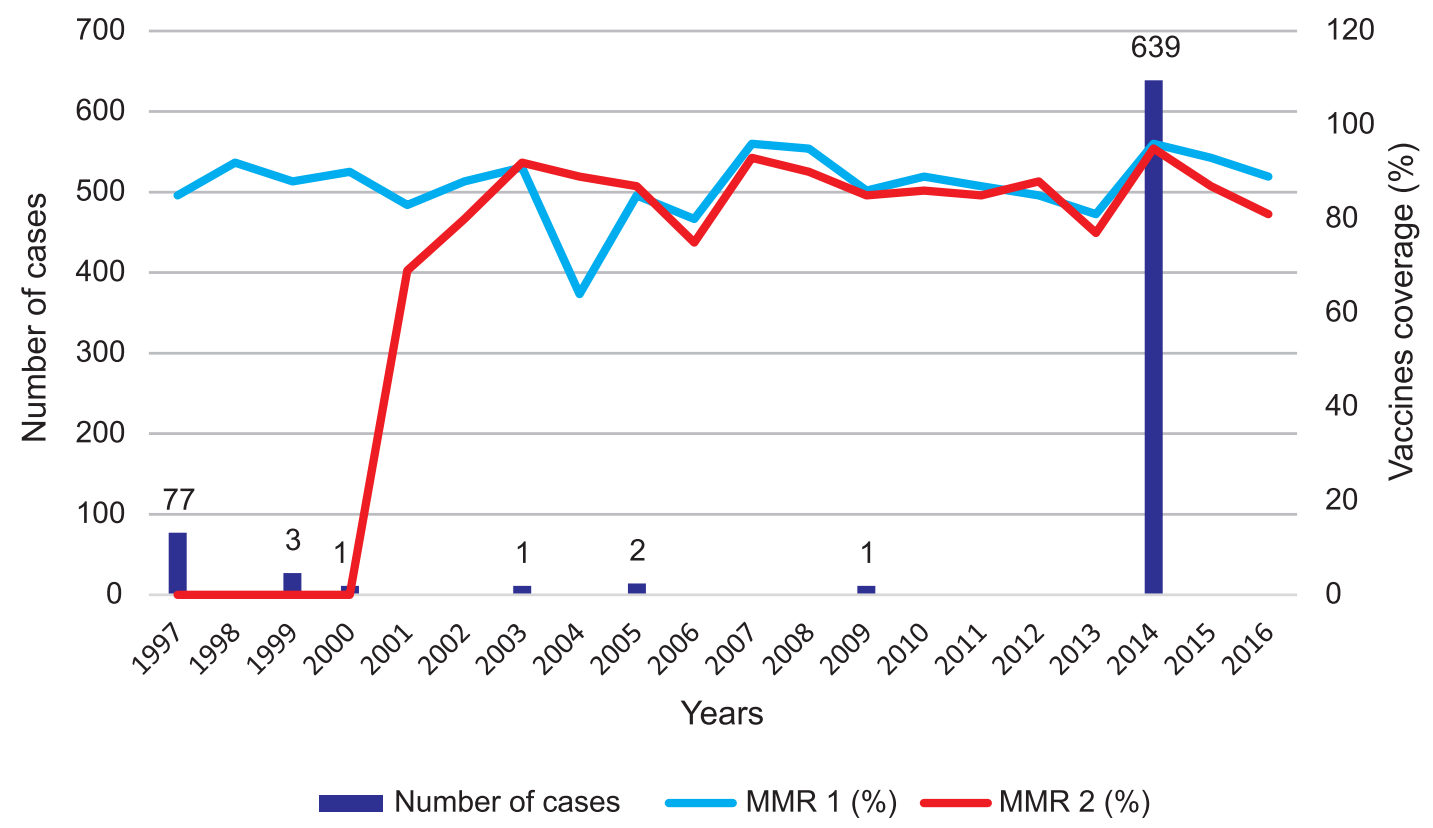

Fig. 2. The number of patients suffering from measles by year, in relation to the coverage by immunization

\section{Results}

In the period from 1997 to 2016 , on average 36 cases of measles occurred each year. In thirteen of those years no cases of the morbidity were registered, but in five years the disease appeared sporadically: 1999 (three cases); 2000 (one); 2003 (one); 2005 (two); and 2009 (one). However, in this period two epidemics occurred: the first in 1997 with 77 affected children, with an incidence rate in the population under consideration of 218/100,000; and in 2014 with an explosion of measles morbidity, when 639 sick children were registered $(1815 / 100,000)$. The average coverage with the first dose of MMR 1 (measles, mumps, and rubella) vaccine in this area over the past twenty years was $86 \%$, and the poorest results were achieved in 2004, with $64 \%$. The average coverage with MMR 2 was $84 \%$ (Fig. 2).

In the period under consideration a total of 716 children were affected by the two epidemics. The first epidemic began in March 1997 and lasted for 5 months. Of the total of 77 affected children, 23 or $29.8 \%$ were of pre-school age (0-6 years), whilst the remaining 54 , or $70.2 \%$, were of school age (7-18 years). Four cases were recorded in children younger than thirteen months. During the major epidemic in 2014, mainly older children were affected. The epidemic, which began in the municipality of Bugojno as the result of an imported virus, spread explosively in a short period to cover the entire Federation of Bosnia and Herzegovina, where in 2014 a total of 3426 affected children were registered, and in 2015 an additional 1677 (12). In the Republika Srpska, the epidemic began two months later, and 1,622 individuals were affected in 2014, whilst in 2015 there was a total of 2410 children (13).

In relation to the two age groups considered, 192 , or $30.05 \%$, of the patients were pre-school children, whilst 447 , or $69.95 \%$, were of school age (Table 2).

Children from rural areas were more frequently affected (56\%) than those from urban areas (44\%) of this region. In relation to the vaccination status, the cohort of affected children aged from 1 to 18 years was consid- 
Table 2 The number of children suffering from measles during the epidemics of 1997 and 2014 in relation to age

\begin{tabular}{llll}
\hline \multirow{2}{*}{$\begin{array}{l}\text { Children's Ages } \\
\text { (Years) }\end{array}$} & \multicolumn{2}{l}{ Epidemics } & Total \\
\cline { 2 - 3 } & 1997 & 2014 & $\mathrm{n} ;(\%)$ \\
\cline { 2 - 4 } & $\mathrm{n} ;(\%)$ & $40(5.58)$ & $44(6.14)$ \\
\hline$<1$ & $4(0.55)$ & $152(21.22)$ & $171(23.88)$ \\
\hline $2-6$ & $19(2.65)$ & $129(18.01)$ & $145(20.25)$ \\
\hline $7-10$ & $16(2.23)$ & $154(21.50)$ & $177(24.72)$ \\
\hline $11-14$ & $23(3.21)$ & $164(22.90)$ & $179(25)$ \\
\hline $15-18$ & $15(2.09)$ & $639(89.24)$ & $716(100)$ \\
\hline Total & $77(10.75)$ & & \\
\hline
\end{tabular}

ered. The largest number of children had not been vaccinated, that is 693 (95.85\%), 19 or $2.62 \%$ were incompletely vaccinated, whilst only 11 or $1.52 \%$ were completely vaccinated. Boys were affected slightly more (54\%) than girls (46\%). The first three cases of measles during the epidemic in 2014 (Bugojno) were confirmed by the European Regional Reference Laboratory for Measles and Rubella in Luxembourg, where it was established that it was the D8 genotype of the virus. Of the total number, 43 (6.72\%) children suffering from measles were hospitalized. During the epidemic no deaths were recorded which could be related to measles.

\section{Discussion}

In the period in question, the occurrence of measles varied. The disease mainly occurred sporadically/endemically, but twice it had the character of an epidemic. The 1997 epidemic was shorter and affected fewer children than the epidemic in 2014. In 2014, the epidemic wave spreading over the entire area of the Central Bosnia Canton was the most severe in the seventh and eighth weeks from the appearance of the disease, whilst the largest number of sick children were registered in the following two weeks. The target coverage by MMR $1(\geq 95 \%)$,which would guarantee the interruption of the endemic persistence of the measles virus $(14,15)$ in the area of the Central Bosnia Canton, was achieved in this period in 2007, 2008 and 2014, whilst the second dose of MMR 2 only achieved this goal in the year of the 2014 epidemic. In the remaining years, omissions were recorded in coverage, which ranged from $31 \%$ in 2004 to $2 \%$ in 2015 (average $7.85 \%$ ), so a significant number of sensitive children were not vaccinated, which led to a weakening in collective immunity, that is, to the situation where a major risk exists of the appearance of an imported virus, of a different genotype, which may cause the occurrence and spread of measles (16). That is to say, in areas where vaccination and re-vaccination are achieved of up to $95 \%$ of children against measles, there is a low probability that the measles virus of a "local" genotype will appear and persist $(17,18)$.

In the 2014 epidemic, the first recorded cases of patients with measles were registered in a family from Bugojno, whose children had spent time in Western Europe (Germany and Italy) during their winter school holidays. In the elementary school the affected children attended, there was an epidemic explosion in February 2014, and in the following two weeks the epidemic spread to other parts of the Central Bosnia Canton.

The measles virus of genotype $\mathrm{D} 8$, which was demonstrated in our patients by genotyping, and was shown by epidemiological research to have been imported into Bosnia 
and Herzegovina in February 2014, was the most frequently identified virus in Europe in 2014 and 2015 (19). The experience of a significant number of European states, including the most developed (the United Kingdom, Italy, Germany, France, Spain etc.) shows that even after a long period of time with no registrations of the disease, the reappearance of measles is possible, and the virus very easily finds individuals and vulnerable groups in the population, causing occasional minor or major epidemics, during which fatalities are also registered $(20,21,22,23)$.

This virus was also responsible for the measles epidemic in Berlin, which began in October 2014. The index case in this epidemic was a child, an asylum seeker from Bosnia and Herzegovina, and the disease later spread to the general population (24). Again, in the occurrence of measles, including 47 unvaccinated cases in the region of Alsace (France), the index case was a pupil who had probably been exposed to measles in Berlin, during a school trip, after contact with a confirmed case whilst staying in a German family. In view of the very low coverage by vaccination of pupils in the school, the virus spread easily (24). The Austrian Public Health Department reported 152 cases of measles between 1 January and 21 April 2015. Five cases were believed to have been imported from abroad: two from Germany, two from Bosnia and Herzegovina, and one from India. Genotype D8 was linked to the epidemics in Bosnia and Herzegovina and Berlin, and was identified in 31 tested samples (24).

The European Regional Verification Commission for Measles and Rubella Elimination, in its report of October 2015, reported that in 32 states (of 53), endemic transmission of measles had been interrupted (report for 2014). Of these countries, $21 \mathrm{had}$ achieved a "sustainable interruption", with three consecutive years without a single case of the disease, and as a result it was deemed that the endemic transmission of the dis- ease had been eliminated (25). Despite this progress, due to several major epidemics, the number of registered cases of measles in the European region almost doubled in 2015 $(30,762)$ in comparison with the number of cases reported in $2014(16,156)$. Neighbouring Croatia reported the highest rate (51.6 cases per million) in 2015 (25).

It is characteristic that the epidemic in 2014 in the Central Bosnia Canton began explosively in urban areas, primarily in schools, and then it gradually moved to rural areas, where it remained longer, seeking out vulnerable individuals. Research in India during a measles epidemic in 2011 showed a higher rate of illness in a rural area (the village of Gorkhi with 44/1000) in comparison with an urban area (27/1000) (26). On the basis of data collected in 40 African countries in 2002-2009, it was found that $33 \%$ of the patients came from urban areas and $67 \%$ from rural areas (27).

Boys were more vulnerable; they fell ill more often and were more often hospitalized than girls. The results of the epidemic in Austria, at the beginning of 2009 , show that of 78 cases, 49 (63\%) were boys and $29(37 \%)$ were girls (28). The Public Health England (PHE) Centre of Infectious Disease Surveillance and Control also reported a larger number of affected boys than girls in the epidemic from 2011 to 2014 (29).

When the epidemic broke out, a strong campaign was launched on the importance of immunization, including health professionals, education workers, the media and religious officials. Thanks to that campaign, the target coverage with MMR 1 (96\%), and MMR 2 (95\%) was achieved (Fig. 2). However, already in the following years, there was a fall in the coverage as the result of the many years of a negative perception of immunization, mentioned in research by Larson $\mathrm{HJ}$ et al. (30), who found that in Bosnia and Herzegovina $36 \%$ of subjects expressed a lack of confidence in the safety of vaccines, and Bos- 
nia and Herzegovina is in second place after France, where the lack of confidence in vaccines is at $41 \%$.

As part of the anti-epidemic measures, immunization has been intensified using the MMR triple vaccine in routine immunization, data are collected, children are invited who previously missed the dates for MMR 1 and MMR 2 vaccinations, and a decision has been rendered to lower the age for MMR 1 to 6 months, and to make it possible to receive MMR 2 up to 18 years of age, when it was missed. For all children who were immunized earlier, the obligation remains to receive a booster vaccination between fifteen and twenty-four months of life.

During the epidemic in the Central Bosnia Canton, no deaths were recorded which could be related to measles. However, in 2014, 114,900 mortalities were registered in the world, which could be related to measles, mainly of children younger than 5 years of age (25). The vast majority (more than 95\%) of measles mortalities occur in countries with low per capita income, and poor health care infrastructure (25).

\section{Conclusion}

The epidemiological occurrence of measles in the area of four municipalities in Central Bosnia is the result of omissions in the routine immunization programme. It is necessary to improve efforts to identify the hindrances to easier acceptance of vaccines, and research methods for identification of susceptible individuals and vulnerable groups, who cannot be reached by the routine immunization programme.

Authors' contributions: Conception and design: SK. and LĐ; Acquisition, analysis and interpretation of data: SK, LĐ, and ŠM; Drafting the article: SK; Revising the article critically for intellectual content: SK, LĐ, ŠM and SM; Approved final version of the manuscript: SK and LĐ.
Conflict of interest: The authors declare that they have no conflict of interest.

\section{References}

1. Hahm B, Arbour N, Naniche D, Homann D, Manchester M, Oldstone MB. Measles virus infects and suppresses proliferation of $\mathrm{T}$ lymphocytes from transgenic mice bearing human signaling lymphocytic activation molecule. J Virol. 2003;77(6):3505-15.

2. World Health Organization. Measles vaccines: WHO position paper. Weekly Epidemiological Record. 2009;84(35):349-60.

3. WHO [homepage on the Internet]. Eliminating measles and rubella and prevention congenital rubella infection, WHO European region strategic plan 2005-2010. [updated 2002 May 16; cited 2017 January 9]. Available from: http://www. euro.who.int/ data/assets/pdf_file/0008/79028/ E87772.

4. World Health Organization, UNICEF. GIVS: Global Immunization Vision and Strategy 20062015. Switzerland: WHO and UNICEF, 2005.

5. Martin R, Wassilak S, Emiroglu N, Uzicanin A, Deshesvoi S, Jankovic D, et al. N. What will it take to achieve measles elimination in the World Health Organization European Region: progress from 2003-2009 and essential accelerated actions. J Infect Dis. 2011;204 (Suppl 1):S325-34.

6. Fiebelkorn AP, Redd SB, Gallagher K, Rota PA, Rota J, Bellini W, et al. Measles in the United States during the postelimination era. J Infect Dis. 2010;202(10):1520-8.

7. Progress in global measles control, 2000-2010. Wkly Epidemiol Rec. 2012;87(5):45-52.

8. Barrabeig I, Rovira A, Rius C, Muñoz P, Soldevila N, Batalla J, Domínguez A. Effectiveness of measles vaccination for control of exposed children. Pediatr Infect Dis J. 2011;1:78-80.

9. The Federal Office of Statistics [homepage on the Internet]. Central Bosnia Canton in figures: Age structure of Population, estimate on 30.06.2015 [in Bosnian], [cited 2017 January 20]: Available from: http://www.fzs.ba/wp-content/uploads/2016/09/ Srednjobosanski-kanton-u-brojkama.pdf.

10. The Federal Office of Statistics [homepage on the Internet]. Central Bosnia Canton in figures: Natural population movements by place of residence in 2015 [in Bosnian], [cited 2017 January 20]: Available from: http://www.fzs.ba/wp-content/ 
uploads/2016/09/Srednjobosanski-kanton-u-brojkama.pdf.

11. WHO [homepage on the Internet]. Guidelines for measles and rubella outbreak investigation and response in the WHO European Region. [cited 2017 January 9]: Available from: http://www.euro. who.int/en/health-topics/communicable-diseases/ measles-and-rubella/publications/2013/guidelinesfor-measles-and-rubella-outbreak-investigationand-response-in-the-who-european-region.

12. The Public Health Institute of the Federation of $\mathrm{BH}$ [homepage on the Internet]. Monthly Newsletter on Trends in Infectious Diseases, PHIFBH, no. 12/15, [in Bosnian], [cited 2017 January 20]: Available from: http://www.zzjzfbih.ba/wp-content/uploads/2012/04/Mjese\%C4\%8Dni-bilteno-kretanju-zaraznih-bolesti-12-2015.-god.pdf.

13. Institute for Public Health of Republic of Serbian [homepage on the Internet]; Infectious and parasitic diseases in the Republic of Serbian territory in 2015; Banja Luka, 2016 [in Serbian]. [cited 2017 February 27]. Available from: http://www. phi.rs.ba/pdf/publikacije/Izvje\%C5\%A1 taj\%20 ZB\%202015\%20-\%20Final\%2021.pdf.

14. Global measles and rubella strategic plan: 2012 2020. Geneva: World Health Organization; 2012.

15. Eliminating measles and rubella and preventing congenital rubella infection: WHO European Region strategic plan 2005-2010. Copenhagen: WHO Regional Office for Europe; 2005.

16. Berggren KL, Tharp M, Boyer KM. Vaccineassociated "wild-type" measles. Pediatr Dermatol. 2005;22(2):130-2.

17. Kutty P, Rota J, Bellini W, Redd BS, Barskey A, Wallace G, Measles vaccine. In: W. Roush WS, Baldy ML, editors, [monograph on the Internet]. Manual for the Surveillance of Vaccine-Preventable Diseases. 6th Ed. Atlanta: Centers for Disease Control and Prevention (CDC);2013. [cited 2017 February 27 9]. Available from: https://www.cdc.gov/ vaccines/pubs/surv-manual/chpt07-measles.pdf.

18. Bedford $H$. Measles and the importance of maintaining vaccination levels. Nurs Times. 2004;100(26):52-5.

19. World Health Organization Measles - WHO European Region. Global Alert And Response (GAR). [cited 2017 February 25]. Available from: http:// www.who.int/csr/don/6-march-2015-measles/en/.

20. Muscat M, Bang H, Glismann S. Measles is still a cause for concern in Europe. Euro Surveill. 2008;13(16).
21. Editorial team Measles once again endemic in the United Kingdom. Euro Surveill. 2008;13(27).

22. Filia A, De Crescenzo M, Seyler T, Bella A, Ciofi Degli Atti ML, Nicoletti L, et al. Measles resurges in Italy: preliminary data from September 2007 to May 2008. Euro Surveill. 2008; 13(29).

23. van Treeck U. Measles outbreak in Germany: over 1000 cases now reported in Nordrhein Westfalen. Euro Surveill. 2006;11(5).

24. European Centre for Disease Prevention and Control [homepage on the Internet]. Measles and rubella monitoring, April 2015 - Reporting on April 2014 to March 2015 surveillance data and epidemic intelligence data to the end of April 2015. [cited 2017 February 25]. Available from: http://ecdc. europa.eu/en/publications/Publications/Measlesrubella-monitoring-second-quarter-2015.pdf.

25. World Health Organization (WHO) [homepage on the Internet]. Fact sheet - Measles in the WHO European Region July 2016. All 53 Member States of the WHO European Region committed in 2010 to the goal of eliminating endemic transmission of measles and rubella. [cited 2017 February 27 9]. Available from: http://www.euro.who.int/_data/ assets/pdf_file/0007/276379/Factsheet-Measlesen.pdf?ua=1.

26. Mishra PP, Chauhan NT. Double outbreak of measles in the talaja block of bhavnagar district, gujarat, India 2011: a need for improving the vaccine coverage and the community participation. J Clin Diagn Res. 2012;6(10):1713-7.

27. Goodson JL, Masresha BG, Wannemuehler K, Uzicanin A, Cochi S. Changing epidemiology of measles in Africa. J Infect Dis. 2011;204 (Suppl 1):S205-14.

28. Martin N, Foxwell AR. Measles status in Australia, and outbreaks in the first quarter of 2009. Commun Dis Intell Q Rep. 2009;33(2):225-31. Erratum in: Commun Dis Intell. 2010;34(2):152.

29. Public Health England [homepage on the Internet]. Measles notifications in England and Wales, by sex. [updated 2015 August 10; cited 2017 January 9]. Available from: www.gov.uk/government/ publications/measles-notifications-by-age-groupregion-and-sex/measles-notifications-in-englandand-wales-by-sex.

30. Larson HJ, de Figueiredo A, Xiahong Z, Schulz WS, Verger P, Johnston IG, et al. The State of Vaccine Confidence 2016: Global Insights Through a 67-Country Survey. EBioMedicine. 2016;12:295301. 